\title{
Hydrothermal catalytic production of fuels and chemicals from aquatic biomass
}

\author{
Thomas M. Yeh, Jacob G. Dickinson, Allison Franck, Suljo Linic, Levi T. \\ Thompson Jr and Phillip E. Savage*
}

\begin{abstract}
One of the promising avenues for biomass processing is the use of water as a reaction medium for wet or aquatic biomass. This review focuses on the hydrothermal catalytic production of fuels and chemicals from aquatic biomass. Two different regimes for conversion of aquatic biomass in hydrothermal conditions are discussed in detail. The first is hydrothermal liquefaction, and the second is hydrothermal gasification. The goals of these processes are to produce liquid-fuel-range hydrocarbons and methane or hydrogen, respectively. The catalytic upgrading of biocrude resulting from noncatalytic liquefaction and the stability and degradation of catalysts in high temperature water are also discussed. The review concludes with a brief discussion of the outlook for and opportunities within the field of hydrothermal catalytic valorization of biomass.
\end{abstract}

(c) 2012 Society of Chemical Industry

Keywords: algae; catalysts; hydrothermal; gasification; liquefaction; bio-oil; biomass

\section{INTRODUCTION}

Concerns over geopolitical and environmental impacts of petroleum use and availability have been growing in recent years. The world's infrastructure for transportation fuels has been optimized around the production, distribution, and use of liquid hydrocarbons from petroleum. Producing liquid hydrocarbon fuels at scale from renewable resources would reduce dependence on petroleum while allowing continued use of the existing fuel infrastructure. The conversion of biomass resources has emerged as an attractive alternative to the production of liquid transportation fuels from petroleum.

Terrestrial plants can be cultivated and processed for fuel production, but they require arable land, fresh water, and fertilizer. The use of each of these natural resources and synthetic fertilizer can have adverse environmental impacts, such as hypoxia from fertilizer runoff into groundwater systems. ${ }^{1,2}$ Additionally, recent reports show that there is not enough land to produce enough biomass to meet the current global demand for liquid fuels. , $^{3,4}$

Aquatic plants offer another option for biomass for biofuels. There has been increasing interest in algae in particular because algal biofuels can potentially address many of the problems associated with terrestrial energy crops. Algae can be grown on marginal lands through the construction of raceway ponds, which provide a closed system (with respect to nutrients) and reduce the risk of fertilizer runoff. Additionally, algae have faster growth rates than terrestrial biomass and can produce one to two orders of magnitude more fuel than terrestrial seed crops on a land area per year basis. When considering diesel alternatives in particular, algae can generate 1000-6000 gasoline gallon equivalents (gge) of biodiesel per acre per year in comparison with soy, which is capable of 45 gge per acre per year. ${ }^{5-7}$

Applying more traditional biofuel production processes (e.g. lipid extraction followed by transesterification, fast pyrolysis, or gasification) to algal biomass requires that the algae be dried prior to use. Since microalgae grow in water only to cell densities of approximately $1 \mathrm{~g} \mathrm{~L}^{-1}$, a tremendous amount of water accompanies the biomass. Producing dry algal biomass necessitates expensive and energy intensive dewatering and drying steps. An alternative route is to convert the aquatic biomass into a crude biooil or hydrocarbon fuel in the aqueous phase, thereby obviating biomass drying. A simple comparison of the enthalpies of liquid water at $350^{\circ} \mathrm{C}$ and water vapor at $50^{\circ} \mathrm{C}$ (i.e. drying the biomass) indicates that processing in liquid water saves $921 \mathrm{~kJ} \mathrm{~kg}^{-1}$.

Hot compressed liquid water near its thermodynamic critical point $\left(T_{C}=373.95^{\circ} \mathrm{C}, P_{C}=22.064 \mathrm{MPa}\right)$ behaves very differently from liquid water at room temperature. As water is heated along its vapor-liquid saturation curve, its dielectric constant decreases due to the hydrogen bonds between water molecules being fewer and less persistent. The reduced dielectric constant enables hot compressed water to solvate small organic molecules, allowing organic reactions to occur in a single fluid phase. ${ }^{8}$ Additionally, the ion product of water increases with temperature up to about $280^{\circ} \mathrm{C}$, but then decreases as the critical point is approached. This higher ion product leads to higher natural levels of hydronium ions in hot compressed water, which can accelerate the rates of acid-catalyzed hydrolytic decomposition reactions.

Hydrothermally processing wet algal biomass at low temperatures (e.g. $200^{\circ} \mathrm{C}$ ) can produce a hydrochar that retains a large proportion of the chemical energy and lipids in the original biomass. We refer to this process as hydrothermal carbonization. These char-bound lipids can be reacted with alcohol to produce biodiesel. ${ }^{9,10}$ Processing the wet aquatic biomass at slightly higher

\footnotetext{
* Correspondence to: P.E. Savage, Department of Chemical Engineering,
} University of Michigan Ann Arbor, MI 48109, USA.Email: psavage@umich.edu

Department of Chemical Engineering, University of Michigan, Ann Arbor, MI 48109, USA 

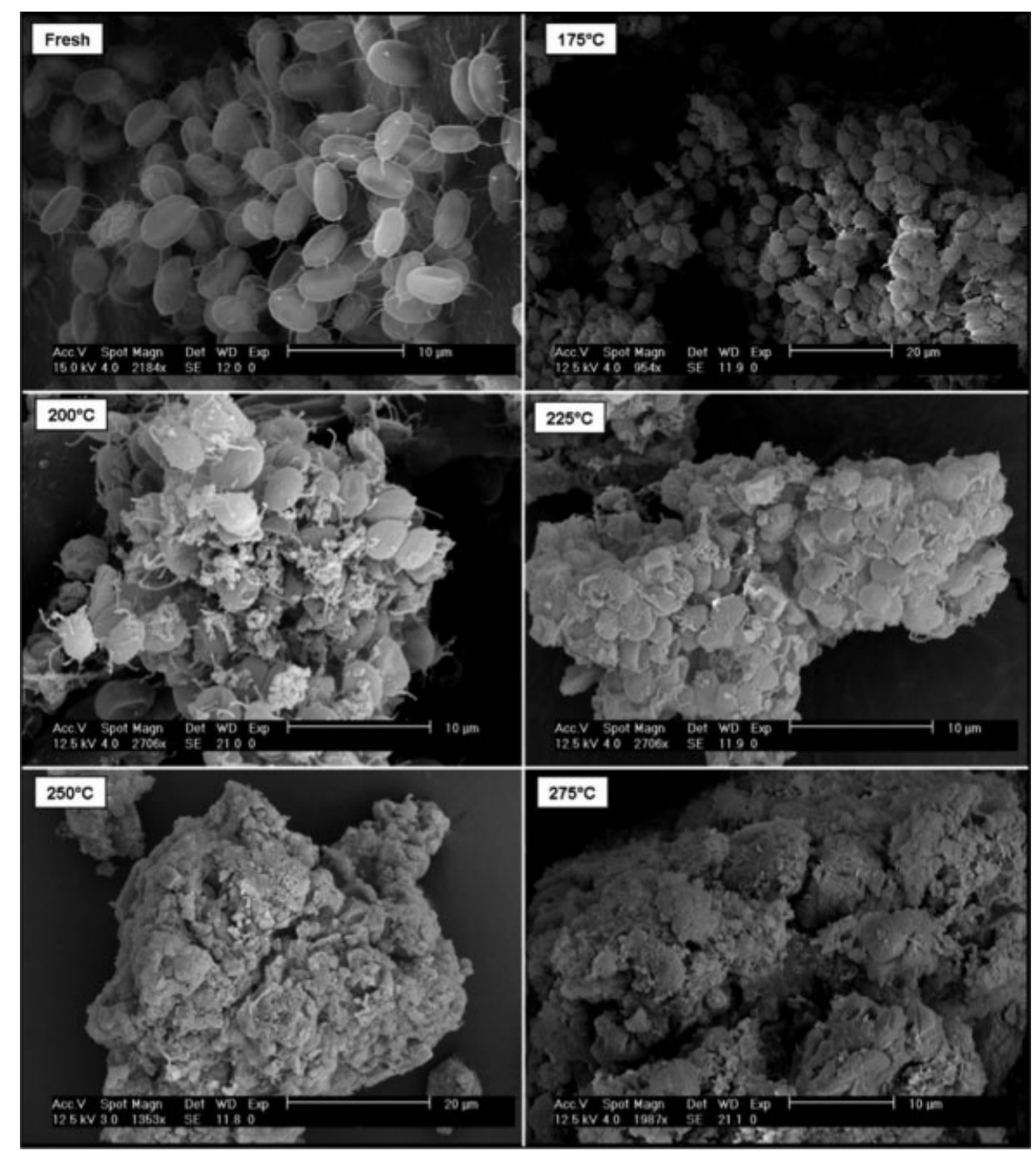

Figure 1. Effect of reaction temperature on algal cells after hydrothermal treatment of Desmodesmus sp. for 5 min reaction time. ${ }^{43}$ (Reprinted with permission from (Garcia Alba L, Torri C, Samor C, van der Spek J, Fabbri D, Kersten SRA, et al. Hydrothermal Treatment (HTT) of Microalgae: Evaluation of the Process As Conversion Method in an Algae Biorefinery Concept. Energy Fuels 2012; doi:10.1021/ef201415s.). Copyright (2012) American Chemical Society.)

temperatures (e.g. $350^{\circ} \mathrm{C}$ ) produces a crude bio-oil. This process is known as hydrothermal liquefaction. Recently, Garcia Alba et al. examined microalgae after a hydrothermal treatment at various temperatures (Fig. 1), and found that below $225^{\circ} \mathrm{C}$ the algal cells did not rupture, providing some insight into the reason for the formation of hydrochar and bio-oil. Using even higher temperatures $\left(\right.$ e.g. $\left.600^{\circ} \mathrm{C}\right)$ converts the algal biomass into gaseous products (primarily $\mathrm{H}_{2}$ and $\mathrm{CH}_{4}$ ). This process is known as hydrothermal gasification or supercritical water gasification (SCWG). What all of these aqueous phase valorization processes have in common is that they use water at elevated temperatures and pressures to break down the biomacromolecules in the aquatic biomass and produce fuels or fuel precursors. A feature that both liquefaction and gasification have in common is that catalysts can be used to accelerate reaction rates and control the ultimate product distribution.

\section{Background and scope}

This review focuses on catalyzed reactions in water above $250^{\circ} \mathrm{C}$ and at pressures that exceed either the vapor pressure of water (at subcritical reaction temperatures) or the critical pressure of water (at supercritical temperatures). Additionally, it focuses exclusively on hydrothermal reactions of aquatic biomass or model systems that are uniquely or directly relevant to aquatic biomass. Published studies of algal biomass conversion in the aqueous phase and hydrothermal reactions of relevant model compounds (e.g. triglycerides, fatty acids, proteins, amino acids, heterocyclic compounds) fall within the scope. The more voluminous literature on hydrothermal studies of lignocellulosic biomass and its model compounds (e.g. lignin, cellulose, sugars, small carboxylic acids, ethers, and alcohols) do not.

The literature provides several reports that complement this present review. Savage ${ }^{8}$ provides a perspective on the field of catalysis in supercritical water in general, and it has a small section devoted to biomass processing. There are reviews on hydrothermal conversion of biomass (primarily terrestrial) or components thereof such as lignin or cellulose. ${ }^{11-13}$ These include both catalyzed and uncatalyzed reactions. Additionally, there are reviews on gasification of organic materials in supercritical water, and these have included previous studies with biomass and related model compounds. ${ }^{14,15}$ One of these reviews focused 
exclusively on catalytic hydrothermal gasification. ${ }^{14}$ None of these reviews, however, are recent enough to have covered new work on gasification of algae in supercritical water. There are also reviews on the conversion of algae to different biofuels, ${ }^{15,16}$ though not necessarily by hydrothermal methods. The promise of aquatic biomass, the advantages associated with processing it in water, the ability of catalysts to control rates and selectivities of chemical reactions, and the absence of any recent review on hydrothermal catalytic methods for conversion of aquatic biomass motivated the preparation of this review.

This review is organized into four major sections. The first section summarizes work done to convert wet algal biomass into a biocrude via hydrothermal catalytic reactions. The second section discusses research in hydrothermal catalysis performed to convert this biocrude into a bio-oil with a lower viscosity, acid number, and heteroatom content. The third section summarizes existing knowledge on the hydrothermal catalytic gasification of algae and aquatic biomass. Within each of these sections we also discuss literature on relevant model compounds reacted with catalysts in a hydrothermal environment. The final section summarizes information available about catalyst deactivation and catalyst stability in hydrothermal reaction media. Table 1 provides an overview of the different catalysts, conditions, and reactants that have been examined to date that are relevant for hydrothermal catalytic processing of aquatic biomass.

\section{Hydrothermal catalytic liquefaction}

The principal role of hydrothermal liquefaction is to decompose the biomacromolecules in the aquatic biomass into smaller molecules that can then be further treated, if desired, to produce specific liquid fuels. Algae consist primarily of proteins, carbohydrates, and lipids, with the specific biochemical content being a function of the species and growth conditions employed. Table 2 provides some representative values for the relative amounts of each component.

The hydrothermal environment promotes the hydrolytic cleavage of ester linkages in lipids, peptide linkages in proteins, and glycosidic ether linkages in carbohydrates. These cleavage reactions can be accelerated by catalysts, and this section reviews studies conducted to investigate the roles for catalysts during liquefaction. We first consider homogeneous catalysis and then turn attention to heterogeneously catalyzed hydrothermal liquefaction.

\section{Homogeneous catalysis}

Homogenous catalysts have received more attention for liquefaction than heterogeneous catalysts, even though homogeneous catalysts are often more difficult to recover after the reaction. Nonetheless, if active and stable homogeneous catalysts are developed, practitioners may be able to overcome these engineering challenges.

By far the most studied homogeneous catalyst for hydrothermal processing of microalgae is $\mathrm{Na}_{2} \mathrm{CO}_{3} \cdot{ }^{17-24}$ The widespread use of $\mathrm{Na}_{2} \mathrm{CO}_{3}$ is because it was previously found to increase the yield of bio-oil from liquefaction of lignocellulosic biomass. ${ }^{25}$ Yang reported that 5 wt $\% \mathrm{Na}_{2} \mathrm{CO}_{3}$ increased the bio-oil yield from the hydrothermal liquefaction of Microcystis viridis from approximately 28 to $33 \%$ at $340^{\circ} \mathrm{C}$ with a $30 \mathrm{~min}$ batch holding time. The energy yield increased from 29.4 to $39.5 \%$ with the addition of $\mathrm{Na}_{2} \mathrm{CO}_{3}$ under the same conditions. ${ }^{23}$ The assertion that $\mathrm{Na}_{2} \mathrm{CO}_{3}$ provides a reducing environment was also supported by the oxygen content in the bio-oil being reduced from 24.2 to $19.7 \mathrm{wt} \%$.
Biller and Ross used various algal strains and model compounds to examine the effects of $\mathrm{Na}_{2} \mathrm{CO}_{3}$ on the liquefaction of the lipid, protein, and carbohydrate fractions of algal cells. ${ }^{17}$ They concluded that lipids and proteins are converted most efficiently without $\mathrm{Na}_{2} \mathrm{CO}_{3}$, whereas $\mathrm{Na}_{2} \mathrm{CO}_{3}$ improved the conversion of carbohydrates.

Interestingly, it has been reported that the effectiveness of $\mathrm{Na}_{2} \mathrm{CO}_{3}$ depends largely on the temperature at which the reactions were performed. Dote, ${ }^{19}$ Inoue $^{20}$ and Minowa ${ }^{18}$ found that increasing the liquefaction temperature from 300 to $340^{\circ} \mathrm{C}$ while employing $\mathrm{Na}_{2} \mathrm{CO}_{3}$ decreased the bio-oil yield. Yang ${ }^{23}$ and Ross ${ }^{21}$ reported the opposite effect. These apparently inconsistent effects may be due to the differences in biochemical compositions of the algal cells, which, as stated above, respond differently to the presence of $\mathrm{Na}_{2} \mathrm{CO}_{3}$. Although the carbohydrate, protein, and lipid contents of the microalgae were not fully reported, the lipid contents reported by Dote $(\sim 50 \%)$ and Minowa ( 20\%) being higher than that in the algae used by Ross support this hypothesis.

In addition to studying the effect of $\mathrm{Na}_{2} \mathrm{CO}_{3}$, Biller, Ross, and coworkers examined the effect of using $\mathrm{KOH}, \mathrm{HCOOH}$, and $\mathrm{CH}_{3} \mathrm{COOH}$ as additives for hydrothermal liquefaction as shown in Table 3. ${ }^{17,21}$ The acetic and formic acids were not catalysts because they were consumed during the reaction. The authors noted that at $350^{\circ} \mathrm{C}$ over $90 \%$ of the organic acids were consumed in the 60 min batch holding time, and were converted mainly to $\mathrm{CO}_{2}$ and $\mathrm{H}_{2} .{ }^{21}$ The catalysts/additives enhanced the bio-oil yield in the order $\mathrm{Na}_{2} \mathrm{CO}_{3}>\mathrm{CH}_{3} \mathrm{COOH}>\mathrm{KOH}>\mathrm{HCOOH}$. The organic acids typically produced a bio-oil with a lower higher heating value (HHV) range $\left(33.3-35.1 \mathrm{MJ} \mathrm{kg}^{-1}\right)$ than did either of the alkali catalysts (33.4-39.9 $\mathrm{MJ} \mathrm{kg}^{-1}$ ) because of an increased O content (13.9 to $9.2 \mathrm{wt} \%$, respectively). At $350^{\circ} \mathrm{C}$, the added organic acids produced a bio-oil that had three times the $\mathrm{S}$ content of that in the bio-oil from liquefaction with added alkali ( 0.6 to $0.2 \%$, respectively), but no significant difference in $\mathrm{N}$ composition ( $\sim 5 \%)$. The organic acids were effective in improving the pour behavior of the bio-oil, although the authors do not expand on the metric used to make this determination. GC/MS total ion chromatograms of the bio-oils show a greater concentration of low molecular compounds in the bio-oils produced with added organic acids compared with the alkali catalyzed reactions. This difference is likely the reason for the improved pour behavior. Though the addition of organic acids improved this property of the bio-oil, it is not obvious that such addition would be feasible in a large-scale process. Factors such as the cost of the organic acid and its source (e.g. from renewable resources vs. from fossil resources) would need to be carefully considered.

The high $\mathrm{N}$ content in microalgae and in their subsequent biooils remains a major challenge to producing commercial fuels. Fuels need to be lower in $\mathrm{N}$ to meet environmental emission standards for combustion. Most of the $\mathrm{N}$ atoms in the liquefaction bio-oils likely originate from the protein fraction of the algae. Therefore, to gain a greater understanding of the interactions of $\mathrm{N}$-containing compounds and catalysts in a hydrothermal environment, several researchers have examined the hydrothermal reactions of proteins and amino acids using homogeneous catalysts. ${ }^{17,26}$ Contradictory reports on the effect of $\mathrm{Na}_{2} \mathrm{CO}_{3}$ on the yield and composition of bio-oil have emerged. Compared with results from liquefaction with no additives, Biller and Ross observed that the yield of bio-oil decreased and its $\mathrm{N}$ content increased when $\mathrm{Na}_{2} \mathrm{CO}_{3}$ was used in the liquefaction of soya protein, asparagine, and glutamine. The use of formic acid had similar effects on the yield and the $\mathrm{N}$ content of the bio-oil, leading the authors to recommend liquefaction without added $\mathrm{Na}_{2} \mathrm{CO}_{3}$ when processing proteins. ${ }^{17}$ 
Table 1. Overview of catalysts used in hydrothermal processing of algae and model compounds

\begin{tabular}{|c|c|c|c|c|}
\hline Catalyst & Feed & Conditions & Effects & Source \\
\hline \multirow[t]{3}{*}{$\mathrm{Na}_{2} \mathrm{CO}_{3}$} & Microcystis viridis & $340^{\circ} \mathrm{C}, 30 \mathrm{~min}$ & $\begin{array}{l}\text { Increased bio-oil yield, energy yield. Reduced oxygen } \\
\text { content. Improves conversion of carbohydrates, but } \\
\text { decreases conversion of proteins }\end{array}$ & [17-24] \\
\hline & Chlorella, spirulina & $350^{\circ} \mathrm{C}, 60 \mathrm{~min}$ & Increased bio-oil yield & {$[17,21]$} \\
\hline & Cellulose slurry & $400^{\circ} \mathrm{C}, 15 \mathrm{~min}$ & $\begin{array}{l}\text { Used to promote a Ni catalyst. Aided in water gas shift. } \\
\text { Least active of alkali carbonates tested }\end{array}$ & {$[55]$} \\
\hline $\mathrm{K}_{2} \mathrm{CO}_{3}$ & Cellulose slurry & $400^{\circ} \mathrm{C}, 15 \mathrm{~min}$ & Used to promote a Ni catalyst. Aided in water gas shift & [55] \\
\hline $\mathrm{Cs}_{2} \mathrm{CO}_{3}$ & Cellulose slurry & $400^{\circ} \mathrm{C}, 15 \mathrm{~min}$ & $\begin{array}{l}\text { Used to promote a Ni catalyst. Aided in water gas shift. Most } \\
\text { active of alkali carbonates tested }\end{array}$ & [55] \\
\hline $\mathrm{LiOH}$ & Pyrocatechol & & Promoted water gas shift reaction & [56] \\
\hline $\mathrm{NaOH}$ & Hexadecane & $400^{\circ} \mathrm{C}$ & $\begin{array}{l}\text { Gas had a high } \mathrm{H}_{2}: \mathrm{CO} \text { ratio, but conversion of } \\
\text { n-hexadecane was not changed by } \mathrm{NaOH}\end{array}$ & [54] \\
\hline \multirow[t]{2}{*}{$\mathrm{KOH}$} & Chlorella, spirulina & $350^{\circ} \mathrm{C}, 60 \mathrm{~min}$ & Increased bio-oil yield & {$[17,21]$} \\
\hline & Pyrocatechol & & Promoted water gas shift reaction & {$[56]$} \\
\hline $\mathrm{HCOOH}$ & Chlorella, spirulina & $350^{\circ} \mathrm{C}, 60 \mathrm{~min}$ & $\begin{array}{l}\text { Increased bio-oil yield. An additive that made } \mathrm{CO}_{2} \text { and } \mathrm{H}_{2} \text {. } \\
\text { Resulted in a bio-oil with a lower } \mathrm{HHV} \text { compared to alkali } \\
\text { catalysts }\end{array}$ & {$[17,21]$} \\
\hline $\mathrm{CH}_{3} \mathrm{COOH}$ & Chlorella, spirulina & $350^{\circ} \mathrm{C}, 60 \mathrm{~min}$ & $\begin{array}{l}\text { Increased bio-oil yield. An additive that made } \mathrm{CO}_{2} \text { and } \mathrm{H}_{2} \text {. } \\
\text { Resulted in a bio-oil with a lower } \mathrm{HHV} \text { compared to alkali } \\
\text { catalysts }\end{array}$ & {$[17,21]$} \\
\hline $\mathrm{Zn}\left(\mathrm{CH}_{3} \mathrm{CO}_{2}\right)_{2}$ & Algae & $450-475^{\circ} \mathrm{C}, 210 \mathrm{bar}$ & $\begin{array}{l}\text { Organic phase with carboxylic acids and unsaturated } \\
\text { compounds, and aqueous phase with C2-C5 carboxylic } \\
\text { acids and glycerol }\end{array}$ & [29] \\
\hline $\mathrm{ZrO}_{2}$ & Stearic acid & $400^{\circ} \mathrm{C}, 30 \mathrm{~min}$ & Bimolecular decarboxylation. $68 \%$ conversion & {$[39,40]$} \\
\hline \multirow[t]{2}{*}{$\mathrm{Pd} / \mathrm{C}$} & Nannochloropsis sp. & $350^{\circ} \mathrm{C}, 60 \mathrm{~min}$ & Increased biocrude yield from 35 to $57 \%$ & [30] \\
\hline & Palmitic and stearic acid & $350^{\circ} \mathrm{C}$ & $\begin{array}{l}\text { Decarboxylation with high selectivity and conversion to } \\
\text { alkanes }\end{array}$ & {$[36,37]$} \\
\hline \multirow[t]{5}{*}{$\mathrm{Pt} / \mathrm{C}$} & Nannochloropsis sp. & $350^{\circ} \mathrm{C}, 60 \mathrm{~min}$ & $\begin{array}{l}\text { Increased the yield of oil, decreased oxygen content, and } \\
\text { increased the energy density compared to non-catalytic } \\
\text { liquefaction }\end{array}$ & [30] \\
\hline & Biocrude from nannochloropsis & $320-340^{\circ} \mathrm{C}, \mathrm{H}_{2}$ & Reduced O, N, S. Reduced oil viscosity. & [31] \\
\hline & Biocrude from nannochloropsis & $430-530^{\circ} \mathrm{C}$ & $\begin{array}{l}\text { Reduced heteroatom content, at } 480 \text { and } 530^{\circ} \mathrm{C} \text {. Increased } \\
\text { aromatics }\end{array}$ & [33] \\
\hline & Palmitic and stearic acid & $350^{\circ} \mathrm{C}$ & $\begin{array}{l}\text { Decarboxylation with high selectivity and conversion to } \\
\text { alkanes }\end{array}$ & {$[36,37]$} \\
\hline & Benzofuran & $380^{\circ} \mathrm{C}, \mathrm{H}_{2}$ & $\begin{array}{l}\text { Ethylbenzene and ethylcyclohexane produced. Benzofuran } \\
\text { inhibits - OH hydrogenolysis }\end{array}$ & [42] \\
\hline $\mathrm{Pt} / \gamma-\mathrm{Al}_{2} \mathrm{O}_{3}$ & Pyridine, $\mathrm{H}_{2}$, water & $250-450^{\circ} \mathrm{C}$ & $\begin{array}{l}\text { The presence of water changed the reaction pathway. } \\
\text { Complete HDN achieved }\end{array}$ & [47] \\
\hline $\mathrm{Ru} / \mathrm{C}$ & Algae & $400-410^{\circ} \mathrm{C}$ & $\begin{array}{l}\text { Effective gasification catalyst. } \mathrm{H}_{2} \text { and } \mathrm{CH}_{4} \text { are the main } \\
\text { products }\end{array}$ & {$[60-62]$} \\
\hline $\mathrm{Ni}$ & Algae & $600^{\circ} \mathrm{C}, 2 \mathrm{~min}$ & $\begin{array}{l}\text { High gasification efficiencies with the major product gases } \\
\text { being } \mathrm{CO}_{2}, \mathrm{CH}_{4} \text {, and } \mathrm{H}_{2}\end{array}$ & [57] \\
\hline Inconel & Algae & $600^{\circ} \mathrm{C}, 2 \mathrm{~min}$ & $\begin{array}{l}\text { High gasification efficiencies with the major product gases } \\
\text { being } \mathrm{CO}_{2}, \mathrm{CH}_{4} \text {, and } \mathrm{H}_{2}\end{array}$ & [57] \\
\hline $\mathrm{Ni} / \mathrm{SiO}_{2}-\mathrm{Al}_{2} \mathrm{O}_{3}$ & Nannochloropsis sp. & $350^{\circ} \mathrm{C}, 60 \mathrm{~min}$ & Active for desulfurization & [30] \\
\hline $\mathrm{NiMo} / \gamma-\mathrm{Al}_{2} \mathrm{O}_{3}$ & Dibenzothiophene & & $\begin{array}{l}\text { A variety of reductants used }-\mathrm{H}_{2}, \mathrm{CO}, \mathrm{HCOOH} . \mathrm{CO} \text { and } \\
\mathrm{HCOOH} \text { more effective for } \mathrm{HDS} \text { than } \mathrm{H}_{2}\end{array}$ & [50] \\
\hline $\mathrm{NiMo} / \gamma-\mathrm{Al}_{2} \mathrm{O}_{3}$ (sulfided) & Quinoline, heptane, SCW & $350-450^{\circ} \mathrm{C}$ & Heptane used as a hydrogen source for HDN & [48] \\
\hline \multirow[t]{2}{*}{$\mathrm{CoMo} / \gamma-\mathrm{Al}_{2} \mathrm{O}_{3}$ (sulfided) } & Nannochloropsis sp. & $350^{\circ} \mathrm{C}, 60 \mathrm{~min}$ & $\begin{array}{l}\text { Increased biocrude yield and decreased } \mathrm{O} \text { in biocrude } \\
\text { when compared with non-catalytic liquefaction }\end{array}$ & [30] \\
\hline & Dibenzothiophene & $350-450^{\circ} \mathrm{C}$ & $\begin{array}{l}\text { HDS performed, no detectable sulfur in resulting benzene } \\
\text { and toluene }\end{array}$ & [49] \\
\hline $\mathrm{Mo}_{2} \mathrm{C}$ & Biocrude from nannochloropsis & $430-530^{\circ} \mathrm{C}$ & $\begin{array}{l}\text { Reduced heteroatom content, at } 480 \text { and } 530^{\circ} \mathrm{C} \text {, increase in } \\
\text { aromatics }\end{array}$ & [33] \\
\hline \multirow[t]{2}{*}{ Zeolite } & Nannochloropsis sp. & $350^{\circ} \mathrm{C}, 60 \mathrm{~min}$ & $\begin{array}{l}\text { Limited change in biocrude properties when compared } \\
\text { with non-catalytic lliquefaction }\end{array}$ & [30] \\
\hline & Biocrude from nannochloropsis & $430-530^{\circ} \mathrm{C}$ & $\begin{array}{l}\text { Reduced heteroatom content, at } 480 \text { and } 530^{\circ} \mathrm{C} \text {, increase } \\
\text { in aromatics }\end{array}$ & [33] \\
\hline \multirow[t]{2}{*}{ Activated carbon } & Glucose & $600^{\circ} \mathrm{C}$ & Effective gasification catalyst, though quickly deactivates & [59] \\
\hline & Palmitic or oleic acid & $370^{\circ} \mathrm{C}$ & $\begin{array}{l}\text { Palmitic gives } C_{8}-C_{15} n \text {-alkanes, and oleic gives } C_{12}-C_{17} \\
n \text {-alkanes }\end{array}$ & [41] \\
\hline
\end{tabular}


Table 2. Composition of different algae ${ }^{51}$

General composition of different algae (\% of dry matter)

\begin{tabular}{|lccc|}
\hline Alga & Protein & Carbohydrates & Lipids \\
\hline Anabaena cylindrica & $43-56$ & $25-30$ & $4-7$ \\
Aphanizomenon flos-aquae & 62 & 23 & 3 \\
Chlamydomonas rheinhardii & 48 & 17 & 21 \\
Chlorella pyrenoidosa & 57 & 26 & 2 \\
Chlorella vulgaris & $51-58$ & $12-17$ & $14-22$ \\
Dunaliella salina & 57 & 32 & 6 \\
Euglena gracilis & $39-61$ & $14-18$ & $14-20$ \\
Porphyridium cruentum & $28-39$ & $40-57$ & $9-14$ \\
Scenedesmus obliquus & $50-56$ & $10-17$ & $12-14$ \\
Spirogyra sp. & $6-20$ & $33-64$ & $11-21$ \\
Arthrospira maxima & $60-71$ & $13-16$ & $6-7$ \\
Spirulina platensis & $46-63$ & $8-14$ & $4-9$ \\
Synechococcus sp. & 63 & 15 & 11 \\
\hline Note: Reprinted from Biotechnol. Adv., 25, Becker EW, Micro-algae as \\
a source of protein, 207-210, Copyright (2007), with permission from \\
Elsevier.
\end{tabular}

Table 3. Atomic content, $\mathrm{HHV}$, yield, and energy balance of biocrudes produced at $350^{\circ} \mathrm{C}$ for $1 \mathrm{~h}^{21}$

\begin{tabular}{|c|c|c|c|c|c|c|c|c|}
\hline Conditions & C & $\mathrm{H}$ & $\mathrm{N}$ & $S$ & $\mathrm{O}^{\mathrm{a}}$ & $\mathrm{HHV}$ & $\begin{array}{l}\text { Bio-crude } \\
\text { yield (daf) }\end{array}$ & $\begin{array}{c}\text { Heat } \\
\text { balance } \\
(\%)\end{array}$ \\
\hline \multicolumn{9}{|l|}{ Spirulina } \\
\hline $1 \mathrm{M} \mathrm{Na}_{2} \mathrm{CO}_{3}$ & 75.4 & 10.8 & 4.6 & 0.5 & 8.7 & 34.8 & 20.0 & 32.8 \\
\hline $1 \mathrm{M} \mathrm{KOH}$ & 74.6 & 511.4 & 5.1 & 0.5 & 8.5 & 33.4 & 15.2 & 23.9 \\
\hline $1 \mathrm{M} \mathrm{HCOOH}$ & 72.7 & 9.8 & 5.7 & 1.0 & 10.9 & 35.6 & 14.2 & 28.3 \\
\hline $1 \mathrm{M} \mathrm{CH}_{3} \mathrm{COOH}$ & 71.7 & 9.7 & 6.1 & 0.9 & 11.6 & 35.1 & 16.6 & 25.3 \\
\hline \multicolumn{9}{|l|}{ Chlorella } \\
\hline $1 \mathrm{M} \mathrm{Na}_{2} \mathrm{CO}_{3}$ & 73.6 & 510.7 & 4.9 & $<0.2$ & 10.7 & 37.1 & 27.3 & 47.7 \\
\hline $1 \mathrm{M} \mathrm{KOH}$ & 74.0 & 12.9 & 4.3 & $<0.2$ & 8.9 & 39.9 & 22.4 & 42.1 \\
\hline $1 \mathrm{M} \mathrm{HCOOH}$ & 70.8 & 39.4 & 5.3 & 0.6 & 13.9 & 35.1 & 19.1 & 37.3 \\
\hline $1 \mathrm{M} \mathrm{CH}_{3} \mathrm{COOH}$ & 69.6 & 99.1 & 5.0 & 0.5 & 15.8 & 33.2 & 20.4 & 29.6 \\
\hline \multicolumn{9}{|c|}{$\begin{array}{l}\text { a By difference. } \\
\text { Note: Reprinted from Fuel, 89(9), Ross A, Biller P, Kubacki M, Li H, } \\
\text { Lea-Langton A, Jones J, Hydrothermal processing of microalgae using } \\
\text { alkali and organic acids, 2234-2243, Copyright 2012, with permission } \\
\text { from Elsevier. }\end{array}$} \\
\hline
\end{tabular}

These results are consistent with recent results from Changi et al., ${ }^{27}$ who showed that adding inorganic compounds increased the conversion of a model amino acid (phenylalanine), but did so by accelerating the pathway to formation of dimers and higher molecular weight material. In contrast, Dote et al. reported that $\mathrm{Na}_{2} \mathrm{CO}_{3}$ decreased the partitioning of $\mathrm{N}$ into the bio-oil produced from liquefying albumin and increased the $\mathrm{N}$ partitioning into the aqueous phase. ${ }^{28}$ At present this difference remains unresolved, but may be simply due to the variations of the biomass model compounds used. Dote et al. also found that increasing the reaction temperature from 150 to $340^{\circ} \mathrm{C}$ and increasing batch holding time from 0.5 to $2 \mathrm{~h}$ increased bio-oil yield, but also increased the nitrogen distribution to the oil when $\mathrm{Na}_{2} \mathrm{CO}_{3}$ was used. In general, the majority ( $~ 90 \%$ ) of the $\mathrm{N}$ from the albumin was partitioned to the aqueous phase regardless of the processing conditions used. ${ }^{28}$
At this point the roles of $\mathrm{Na}_{2} \mathrm{CO}_{3}$ and formic acid as potential catalysts or promoters for the liquefaction of proteins remain unclear. From the literature surveyed, $\mathrm{Na}_{2} \mathrm{CO}_{3}$ does not have any clear positive effect on reducing $\mathrm{N}$ content of bio-oil, rather, there is compelling evidence that it actually increases the $\mathrm{N}$ content while reducing the bio-oil yield. Formic acid was shown to have no positive effects. The complexities and engineering challenges of using the aforementioned additives for high protein algal strains makes the use of homogeneous catalysts undesirable for such feedstocks.

In addition to experiments using alkali catalysts and organic acids, there has been some work done on liquefaction of model systems using $\mathrm{Zn}\left(\mathrm{CH}_{3} \mathrm{CO}_{2}\right)_{2}$. Catalytic hydrothermolysis, which produces non-ester biofuels with high levels of cyclics and aromatics, is an alternative to converting triglycerides into biodiesel. ${ }^{29}$ Li studied the conversion of a variety of crop oils, but the results can be adapted to other triglyceride feedstocks as well. Li found that the use of hot compressed water helps to minimize the formation of less valuable char and gaseous products. The authors claimed that aqueous processing reduces the amount of $\mathrm{H}_{2}$ needed for the conversion, as it is supplied by the water. $\mathrm{Li}$ studied soybean oil, jatropha oil and tung oil from 450 to $475^{\circ} \mathrm{C}$ at 210 bar using $\mathrm{Zn}\left(\mathrm{CH}_{3} \mathrm{CO}_{2}\right)_{2}$ (decomposition temperature of $237^{\circ} \mathrm{C}$ ) as the catalyst. This process produced two liquid phases: organic (approximately $85 \%$ of initial oil mass) and aqueous. The organic phase contained carboxylic acids, unsaturated compounds, and other oxygenated molecules that can then be further refined. The aqueous phase contained $\mathrm{C}_{2}-\mathrm{C}_{5}$ carboxylic acids, glycerol and trace amounts of small polar molecules. Refinement of the organic phase produced a high-grade non-ester biofuel (JP-8, naval distillate and gasoline fractions) in 40 to $52 \%$ yield.

\section{Heterogeneous catalysis}

Heterogeneous catalysts may provide a more attractive option than homogeneous catalysts for processing microalgae through a catalytic hydrothermal liquefaction because heterogeneous catalysts are easier to separate from the reaction products. Duan and Savage ${ }^{30}$ recently studied the hydrothermal liquefaction of microalgae using a variety of common catalysts $(\mathrm{Pd} / \mathrm{C}, \mathrm{Pt} / \mathrm{C}$, $\mathrm{Ru} / \mathrm{C}, \mathrm{Ni} / \mathrm{SiO}_{2}-\mathrm{Al}_{2} \mathrm{O}_{3}, \mathrm{CoMo} / \gamma-\mathrm{Al}_{2} \mathrm{O}_{3}$ (sulfided), and zeolite) under hydrogen and helium atmospheres at $350^{\circ} \mathrm{C}$ for $60 \mathrm{~min}$. The yield of crude bio-oil in the absence of catalysts was $35 \%$ and increased to $57 \%$ when the $\mathrm{Pd} / \mathrm{C}$ catalyst was used without added hydrogen. The authors reported that in the presence or absence of hydrogen the crude bio-oil yield was largely insensitive to the catalyst used. Furthermore, they found that the $\mathrm{Ni} / \mathrm{SiO}_{2}-\mathrm{Al}_{2} \mathrm{O}_{3}$ catalyst was the most active for desulfurization. It is important to note that in this study, the catalysts received no pretreatment (e.g. reduction) prior to being used in the reactions, as is common in conventional hydrotreating. Also, the microalgae used was a marine species that was placed in preservative solution prior to shipment from the producer. Both of these choices in the experimental procedure may have had significant effects on the results and are worthy of further investigation.

\section{Hydrothermal catalytic upgrading}

Though desirable and benefiting from process simplicity, producing a useful biofuel directly from wet microalgae paste in one step and in one pot has not yet been demonstrated. Rather, it appears that processing steps will need to follow the initial liquefaction process to produce a useful fuel. Even if onestep catalytic liquefaction were technically feasible, it could be 


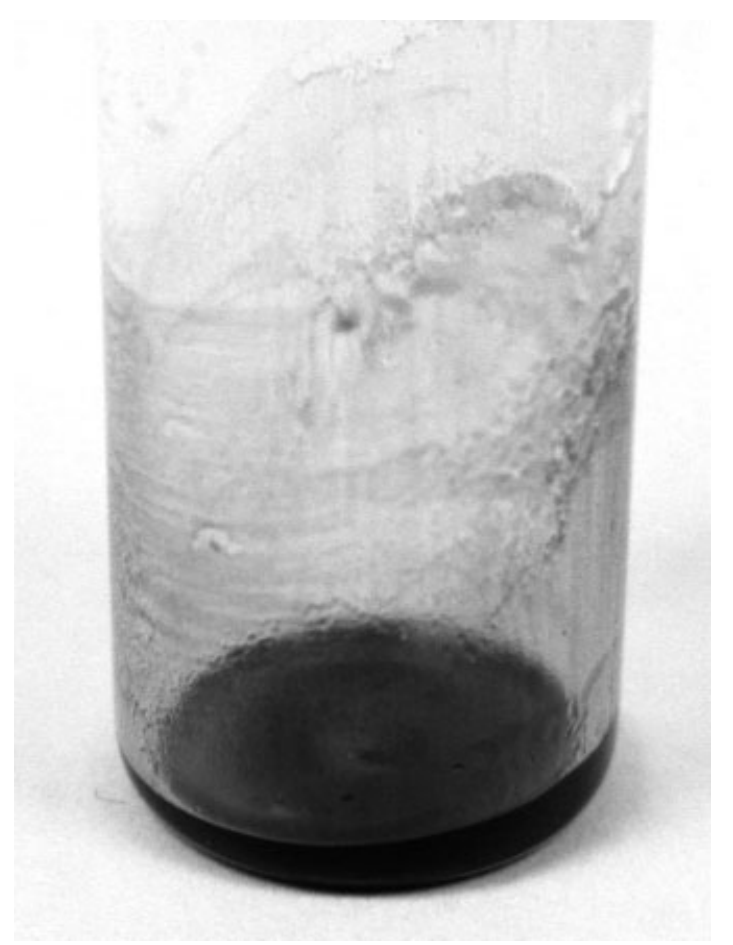

Figure 2. Light fraction (soluble in $n$-hexane) of bio-oil from noncatalytic liquefaction.

problematic from the perspective of recycling the water and nutrients in the aqueous phase as some of the metal catalyst might be leached into the aqueous phase at the reaction conditions. The presence of heavy metals in the aqueous product could render it toxic to algae and make it difficult to recycle or discharge for treatment.

Hydrothermal catalytic upgrading is a processing step that can follow noncatalytic hydrothermal liquefaction. The bio-oil resulting from noncatalytic liquefaction, an example of the light fraction (soluble in $n$-hexane) is shown in Fig. 2 , is typically too viscous to flow at room temperature, has a high oxygen content, and contains too much nitrogen and sulfur for direct use as fuel. The aims of the hydrothermal upgrading step are to remove heteroatoms $(\mathrm{N}, \mathrm{S}, \mathrm{O})$, reduce viscosity, reduce the acid number, and increase heating value. These aims can be accomplished through the use of heterogeneous catalysts.

\section{Upgrading crude bio-oil}

Duan and Savage performed several studies on upgrading the biooil obtained from the noncatalytic liquefaction of Nannochloropsis sp. at 320 or $340^{\circ} \mathrm{C}^{31-33}$ These studies determined that bio-oil upgrading in supercritical water at $400^{\circ} \mathrm{C}$ for $4 \mathrm{~h}$ was most effective when a $\mathrm{Pt} / \mathrm{C}$ catalyst was used along with a hydrogen atmosphere. The oxygen content of the bio-oil dropped from 6.5 to $4.5 \mathrm{wt} \%$, the nitrogen content decreased from 4.9 to $2.2 \mathrm{wt} \%$, and the sulfur content decreased from $0.7 \mathrm{wt} \%$ to below the detection limits for the elemental analysis. Furthermore, the viscosity of the bio-oil was reduced, producing a freely flowing liquid at room temperature. ${ }^{31}$ The total ion chromatograms, shown in Fig. 3, indicate that bio-oil upgraded with $\mathrm{Pt} / \mathrm{C}$ has an increased abundance of volatile (early eluting) compounds and a decreased abundance of compounds with low volatility (late eluting). This finding agrees with the observed decrease in viscosity. In a follow-up article, ${ }^{33}$ the

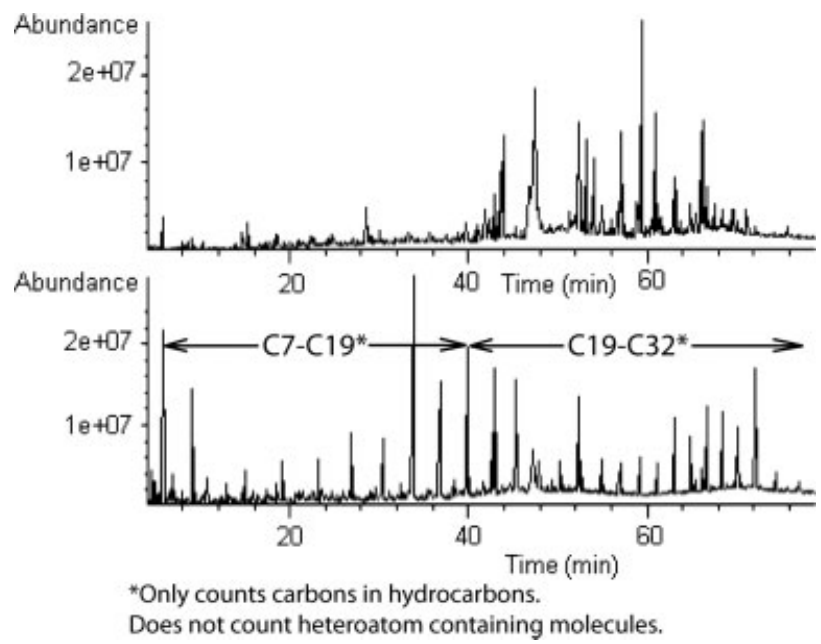

Figure 3. Total ion chromatograms from crude bio-oil (top) and upgraded product oil (bottom) obtained from SCW treatment with $\mathrm{Pt} / \mathrm{C}, \mathrm{H}_{2} .{ }^{31}$ (Reprinted from Bioresource Technology, 102, Peigao Duan and Phillip E. Savage, Ugrading of crude algal bio-oil in supercritical water, 1899-1906. Copyright 2012, with permission from Elsevier). ${ }^{31}$

authors used an optimization algorithm to examine the effects of catalyst loading, catalyst type, reaction time, and temperature on upgrading of the same crude bio-oil. This study showed that $\mathrm{Mo}_{2} \mathrm{C}$, $\mathrm{HZSM}-5$, and $\mathrm{Pt} / \mathrm{C}$ were all effective for upgrading crude bio-oil into a product that had a significant reduction in heteroatom content for all the temperatures examined $\left(430,480\right.$, and $\left.530^{\circ} \mathrm{C}\right)$. At 480 and $530^{\circ} \mathrm{C}$, there was a significant reduction in the $\mathrm{H} / \mathrm{C}$ ratio of the upgraded bio-oils, indicating the increased presence of aromatic compounds. Table 4 shows the optimum conditions for various properties of the bio-oil, and the relative importance of each process variable as determined by the optimization algorithm. In the parameter space examined, a reaction at $430^{\circ} \mathrm{C}$ for $6 \mathrm{~h}$ with a $\mathrm{Mo}_{2} \mathrm{C}$ catalyst was found to be the most effective for upgrading. ${ }^{33}$ Lastly, using $5 \mathrm{wt} \% \mathrm{Pd} / \mathrm{C}$ at $400^{\circ} \mathrm{C}$, these authors examined the effects of catalyst loading (5 to $80 \mathrm{wt} \%$ ) and batch holding time ( 1 to $8 \mathrm{~h}$ ) on the composition of the upgraded bio-oil. They determined that increasing the batch holding time and catalyst loading generally had positive effects on the upgraded bio-oil by decreasing the $\mathrm{O} / \mathrm{C}$ and N/C ratios, and increasing the HHV (44 MJ $\mathrm{kg}^{-1}$ ) and $\mathrm{H} / \mathrm{C}$ ratio of the product oil. ${ }^{32}$

\section{Model compounds}

Previous studies 34,35 revealed the types of molecules present in crude bio-oil from hydrothermal liquefaction of algae. This molecular characterization motivated experiments with simpler model systems to understand better the catalytic reactions involved in hydrothermal upgrading. The model compounds selected contained the types of structures and heteroatom functional groups that are present in the crude bio-oil.

The oxygenated compounds in bio-crude that were amenable to GC-MS analysis were mainly fatty acids, heterocyclic oxygen compounds, and ketones. ${ }^{34}$ The results from Duan et al., which showed that $\mathrm{Pt} / \mathrm{C}$ and $\mathrm{Pd} / \mathrm{C}$ were good catalysts for hydrothermal upgrading of crude bio-oil, are consistent with model compound studies by $\mathrm{Fu}$ and coworkers. ${ }^{36,37}$ They showed that $\mathrm{Pt} / \mathrm{C}$ is an effective catalyst for removing $\mathrm{O}$ atoms from palmitic and stearic acids, ${ }^{36,37}$ which represent common fatty acids present in the biocrude. The authors reported an $80 \%$ yield to pentadecane from palmitic acid in $1 \mathrm{~h}$ at $350^{\circ} \mathrm{C}$. Pd/C was also an effective 


\begin{tabular}{|c|c|c|}
\hline Property & Optimal conditions & Relative importance of factors investigated \\
\hline wt\% O (low) & $530^{\circ} \mathrm{C}, 6 \mathrm{~h}, \mathrm{Mo}_{2} \mathrm{C}, 20 \%$ & $\mathrm{~T}>$ catalyst loading $>\mathrm{t}>$ catalyst type \\
\hline wt\% N (low) & $530^{\circ} \mathrm{C}, 6 \mathrm{~h}, \mathrm{HZSM}-5,10 \%$ & $\mathrm{~T}>\mathrm{t}>$ catalyst loading $>$ catalyst type \\
\hline $\mathrm{H} / \mathrm{C}$ (high) & $430{ }^{\circ} \mathrm{C}, 2 \mathrm{~h}, \mathrm{Pt} / \mathrm{C}, 10 \%$ & $\mathrm{~T}>\mathrm{t}>$ catalyst type $>$ catalyst loading \\
\hline $\mathrm{O} / \mathrm{C}$ (low) & $530{ }^{\circ} \mathrm{C}, 6 \mathrm{~h}, \mathrm{Mo}_{2} \mathrm{C}, 20 \%$ & $\mathrm{~T}>$ catalyst loading $>\mathrm{t}>$ catalyst type \\
\hline N/C (low) & $530^{\circ} \mathrm{C}, 6 \mathrm{~h}, \mathrm{Pt} / \mathrm{C}, 10 \%$ & $\mathrm{~T}>\mathrm{t}>$ catalyst loading $>$ catalyst type \\
\hline HHV (high) & $430^{\circ} \mathrm{C}, 6 \mathrm{~h}, \mathrm{Mo}_{2} \mathrm{C}, 20 \%$ & $\mathrm{~T}>$ catalyst loading $>\mathrm{t}>$ catalyst type \\
\hline Total area $\%$ of fatty acids (low) & $530^{\circ} \mathrm{C}, 6 \mathrm{~h}, \mathrm{HZSM}-5,20 \%$ & $\mathrm{~T}>$ catalyst type $>\mathrm{t}>$ catalyst loading \\
\hline Total area \% of saturated compounds (high) & $430^{\circ} \mathrm{C}, 4 \mathrm{~h}, \mathrm{Mo}_{2} \mathrm{C}, 10 \%$ & $\mathrm{~T}>$ catalyst type $>$ catalyst loading $>\mathrm{t}$ \\
\hline Total area \% of N-containing compounds (low) & $530^{\circ} \mathrm{C}, 2 \mathrm{~h}, \mathrm{HZSM}-5,10 \%$ & $\mathrm{~T}>$ catalyst type $>\mathrm{t}>$ catalyst loading \\
\hline Total area \% of $\mathrm{N}, \mathrm{O}-$ containing compounds (low) & $530^{\circ} \mathrm{C}, 6 \mathrm{~h}, \mathrm{HZSM}-5,10 \%$ & $\mathrm{~T}>$ catalyst type $>\mathrm{t}>$ catalyst loading \\
\hline
\end{tabular}

Note: Reprinted by permission of The Royal Society of Chemistry. Duan P, Savage PE. Catalytic treatment of crude algal bio-oil in supercritical water: optimization studies. Energy Environ Sci. 2011; 4:1447-1456. doi:10.1039/COEE00343C.

catalyst for decarboxylation, but it had lower activity in the hydrothermal environment than did $\mathrm{Pt} / \mathrm{C}$. The reverse trend was found to be true for the catalytic activity of $\mathrm{Pt} / \mathrm{C}$ and $\mathrm{Pd} / \mathrm{C}$ for decarboxylation in an organic solvent, ${ }^{38}$ thereby demonstrating that catalyst behavior in hot compressed water cannot simply be inferred from catalyst behavior in organic media. Pt/C was also effective for the decarboxylation of unsaturated fatty acids, which are common in biocrude, but the catalyst would first hydrogenate the double bond(s) in the fatty acid prior to decarboxylation. ${ }^{36}$ The prevalence of facile hydrogenation was unexpected since no $\mathrm{H}_{2}$ was added to the reactor. The source of the hydrogen was not clear, and it could come either from the fatty acid reactant or the water molecules present.

While Pt/C primarily promotes monomolecular decarboxylation, metal oxides have been reported to promote bimolecular decarboxylation. ${ }^{39,40}$ Of the materials investigated, $\mathrm{ZrO}_{2}$ shows the highest activity with approximately $68 \%$ conversion of stearic acid at $400^{\circ} \mathrm{C}$ for $30 \mathrm{~min}$. $\mathrm{KOH}$ was also studied as a catalyst used to decarboxylate stearic acid. Larger products appeared, and the activity was inferior to heterogeneous catalysts, as will be discussed later. Regardless of whether the catalyst was a precious metal, metal oxide, or simply activated carbon, the main products from stearic acid were $\mathrm{CO}_{2}$ and $\mathrm{C}_{17}$ alkanes. ${ }^{36,37,39,41}$

Dickinson et al. studied the hydrodeoxygenation of benzofuran over $\mathrm{Pt} / \mathrm{C}$ in supercritical water ${ }^{42}$ at $380^{\circ} \mathrm{C}$. They reported the effects of batch holding time, hydrogen loading, catalyst loading, and water loading on the reaction products. Ethylbenzene and ethylcyclohexane were the main deoxygenated products, and the selectivity to ethylbenzene could be increased by increasing the water loading or decreasing the hydrogen loading. Experiments with the oxygen-containing reaction intermediates (e.g. ethylphenol) showed that benzofuran had an inhibitory effect on the hydrogenolysis of the hydroxyl group on ethylphenol to produce ethylbenzene. The authors put forth a reaction network and developed a kinetic model that was consistent with the experimental findings. The model suggested that water was not an important source of hydrogen for this reaction under the conditions studied.

Heterocyclic N-containing compounds are major carriers of nitrogen in bio-oil produced from hydrothermal liquefaction. ${ }^{34,35,43-47}$ Hydrothermal heterogeneous catalytic denitrogenation of model heterocyclic $\mathrm{N}$-containing compounds has been the focus of two recent studies. ${ }^{47,48}$ Yuan et al. used the partial oxidation of heptane in supercritical water (SCW) to produce hydrogen for the hydrodenitrogenation of quinoline. ${ }^{48}$ The researchers found that $\mathrm{N}$ was removed from quinoline at 350 and $450^{\circ} \mathrm{C}$ over a sulfided $\mathrm{NiMo} / \gamma-\mathrm{Al}_{2} \mathrm{O}_{3}$ catalyst. Interestingly, this work also found that partial oxidation of the heptane occurred even without adding $\mathrm{O}_{2}$ to the reactor, although $\mathrm{O}_{2}$ did enhance the reaction rate. This result indicated that the SCW provided a strong enough oxidation environment to produce $\mathrm{CO}$ and the subsequent $\mathrm{CO}_{2}$ and $\mathrm{H}_{2}$ through the water gas shift reaction.

Duan and Savage examined the denitrogenation of pyridine in a hydrothermal medium with added $\mathrm{H}_{2}{ }^{47}$ They examined a variety of catalysts (Pt/C, Pd/C, Ru/C and $\mathrm{Rh} / \mathrm{C}$, sulfided $\mathrm{Pt} / \mathrm{C}, \mathrm{Pt} / \gamma$ $\mathrm{Al}_{2} \mathrm{O}_{3}$, sulfided $\mathrm{CoMo} / \gamma-\mathrm{Al}_{2} \mathrm{O}_{3}, \mathrm{Mo}_{2} \mathrm{C}$, and $\mathrm{Mo}_{2} \mathrm{~S}$ ) at temperatures between 250 and $450^{\circ} \mathrm{C}$. Most interestingly, it was found that performing reactions in a hydrothermal medium significantly alters the reaction pathway of pyridine when using $\mathrm{Pt} / \gamma-\mathrm{Al}_{2} \mathrm{O}_{3}$. In the absence of water, pentane was the major reaction product and the yield of butane was about one fourth that of pentane. In the presence of water at $0.025 \mathrm{~g} \mathrm{~cm}^{-3}$, the yields of butane and pentane were equal. Increasing the water density to $0.1 \mathrm{~g} \mathrm{~cm}^{-3}$ caused a further reduction in pentane yield, such that the ratio of butane to pentane was about 3:1. In all cases (with or without water) the yield of ammonia was always around $100 \%$ indicating that complete denitrogenation had occurred.

The final major heteroatom that is present in aquatic biomass and bio-oils produced from their liquefaction is sulfur. Since sulfur can be present as a heterocyclic organosulfur compound, benzothiophene and dibenzothiophene have been studied as model sulfur compounds for desulfurization in supercritical water. ${ }^{49,50}$ Yuan et al. reacted benzothiophene between 350 and $450^{\circ} \mathrm{C}$ using a sulfided-CoMo $/ \gamma-\mathrm{Al}_{2} \mathrm{O}_{3}$ catalyst. Under these conditions, no sulfurcontaining products were detected in the resulting oil. The only compounds present after reaction were ethyl benzene and toluene while sulfur was released as hydrogen sulfide. ${ }^{49}$ Dibenzothiophene can also undergo hydrodesulfurization using a $\mathrm{NiMo} / \gamma-\mathrm{Al}_{2} \mathrm{O}_{3}$ catalyst. Desulfurization of dibenzothiophene was accomplished using a variety of reductants $\left(\mathrm{H}_{2}, \mathrm{CO}, \mathrm{CO}\right.$ and $\mathrm{H}_{2}$, and $\left.\mathrm{HCOOH}\right)$, and, suprisingly, all the alternative reductants provided higher conversions of dibenzothiophene than did $\mathrm{H}_{2}$. The authors suggest that an active chemical species is formed from the water gas shift reaction causing the higher conversion of dibenzothiophene. ${ }^{50}$ It is also important to point out that $\mathrm{S}$ is the heteroatom that appears to be the easiest to remove from hydrothermal liquefaction bio-crudes. Treatment of crude bio-oil in supercritical water, even without a catalyst, reduced the sulfur content to below detection limits. ${ }^{31}$ 
Contrasting the results of the hydrothermal heterogeneous catalytic liquefaction and the hydrothermal upgrading of crude bio-oil produced from uncatalyzed hydrothermal liquefaction leads to several conclusions. First, heterogeneous catalysts can be used to significantly affect the yield and composition of the biooil. The catalysts resulted in increased yields, decreased viscosity, and decreased $\mathrm{O}, \mathrm{N}$, and $\mathrm{S}$ content. These are desirable bio-oil transformations. Second, the two-stage process of liquefaction and subsequent upgrading reduced the heteroatom content of the crude bio-oil much more than the single stage, one-pot hydrothermal heterogeneous catalytic liquefaction. The reason for this difference has not been examined, but we suspect it may be caused by more rapid deactivation or fouling of the catalyst during the single stage reaction. Research determining the reasons for these differences and developing strategies for reducing catalyst fouling and deactivation would provide a significant advance in this field. Catalyst deactivation in high temperature water will be discussed in greater depth later. Third, the most effective catalysts were supported noble metals. The high cost of these noble metals may be prohibitive to the implementation of these processes at large scale if the catalysts deactivate quickly. Research is needed to develop effective non-noble metal (e.g. CoMo or NiMo) catalysts or to develop stable noble metal catalysts.

\section{Hydrothermal catalytic gasification}

Gasification is the process of partial oxidation of a biomass feedstock using either air, oxygen, or water. The resulting product is a combustible gas that can be used directly or further processed into higher value products. Hydrothermal gasification operates at lower temperatures than those employed in traditional gasification of dry biomass feedstocks. The temperatures for hydrothermal gasification are typically higher than those used for hydrothermal liquefaction, but there is some overlap in operating conditions near the critical point of water.

The ultimate goals of hydrothermal liquefaction and hydrothermal gasification are fundamentally different. With hydrothermal liquefaction, the aim is to preserve the $\mathrm{C}-\mathrm{C}$ bonds in order to synthesize liquid fuels within certain carbon ranges i.e. $C_{4}-C_{12}$ for gasoline and $C_{10}-C_{15}$ for diesel. When the goal is gasification, however, the aim is to break $\mathrm{C}-\mathrm{C}$ bonds to produce gases such as methane or hydrogen. In general, the major product, either methane or hydrogen can be selected through selection of the processing temperature. Following thermodynamics, lower temperatures favor the production of methane while higher temperatures favor the formation of hydrogen.

Investigations into the hydrothermal gasification of algae in sub and supercritical conditions are limited. More commonly, the hydrothermal gasification literature investigates the gasification of cellulose, lignin, and organic waste, and accordingly, glucose is often chosen as a model compound. While glucose is chosen as a model compound for cellulose, it can also be representative of carbohydrates which can be present up to $64 \mathrm{wt} \%$ in algae, depending on the strain. ${ }^{51}$

\section{Homogeneous catalysts}

Alkali compounds, the primary homogeneous catalysts used in hydrothermal gasification, are generally listed as homogeneous catalysts in supercritical water conditions, but these inorganic compounds become less soluble with increasing temperature and decreasing water density. Since the dielectric constant of water decreases as its density decreases, the solubility of ionic substances decreases substantially. At supercritical conditions, $\mathrm{KOH}$ is only soluble upwards of $600 \mathrm{mg} \mathrm{kg}^{-1}$ depending on the water density. ${ }^{52}$ The same behavior is exhibited in $\mathrm{Na}_{2} \mathrm{CO}_{3} .{ }^{53}$ Therefore, in studies that employ these homogeneous catalysts, a significant fraction of the loaded homogenous catalysts could exist as insoluble solids at reaction conditions. Nonetheless, we examine these alkali compounds as homogeneous catalysts due to the solubility of a small fraction of the catalyst in the supercritical fluid.

Alkali compounds such as $\mathrm{NaOH}$ and $\mathrm{Na}_{2} \mathrm{CO}_{3}$ have been shown to be effective gasification catalysts. $\mathrm{NaOH}$ is effective in gasification of hexadecane..$^{54}$ Hexadecane was gasified at $400^{\circ} \mathrm{C}$ in supercritical water, and showed a high ratio of $\mathrm{H}_{2}$ : $\mathrm{CO}$ indicating that the catalyst could assist in promoting the water gas shift reaction. The conversion of n-hexadecane, however, was unchanged by the addition of $\mathrm{NaOH}$. The heavier alkali metals promote the water gas shift reaction more than the lighter metals. ${ }^{55,56} \mathrm{LiOH}$ and $\mathrm{KOH}$ were used in the gasification of pyrocatechol, ${ }^{56}$ and both promoted the water gas shift reaction, but $\mathrm{KOH}$ had greater activity. Additionally, different alkali carbonates, $\mathrm{Na}_{2} \mathrm{CO}_{3}, \mathrm{~K}_{2} \mathrm{CO}_{3}$, and $\mathrm{Cs}_{2} \mathrm{CO}_{3}$ were studied in conjunction with $\mathrm{Ni}$. The order of water gas shift promotion was $\mathrm{Cs}>\mathrm{K}>\mathrm{Na} .{ }^{55}$

Gasification reactions usually have an associated gasification efficiency, which is a measure of the percentage of carbon from biomass becoming gaseous carbon. The gasification efficiency is generally less than unity unless high temperatures and high catalyst loadings are used to drive a reaction as shown in Fig. 4. At times, lower gasification efficiencies can be attributed to interactions between components in the biomass being gasified, which lead to larger molecules and char precursors. For example, Chakinala et al. investigated glycerol gasification in the presence of three different amino acids, L-alanine, glycine, and L-proline, over $\mathrm{K}_{2} \mathrm{CO}_{3}$ and revealed that the presence of $\mathrm{L}$-proline produced heavier products, possibly due to Maillard-type reactions. ${ }^{57}$

\section{Heterogeneous catalysts}

Heterogeneous catalysts are attractive for gasification because they offer better selectivity, and can also be more easily recovered than homogeneous catalysts. ${ }^{58}$ Most of the work involving heterogeneous catalysts has focused on $\mathrm{Ni}$ and $\mathrm{Ru}$ base metals and alloys, and to a lesser extent, activated carbon.

Using high temperatures for gasification $\left(\sim 600^{\circ} \mathrm{C}\right)$ allows nickel to have sufficient gasification activity to make it a potential alternative to precious metal catalysts. Chakinala et al. performed reactions in capillary quartz reactors at $600^{\circ} \mathrm{C}$ for $2 \mathrm{~min}$. They found that $\mathrm{Ni}$ and Inconel gave the highest gasification efficiencies for algae, whereas $\mathrm{Ru}$ and PtPd did not perform as well. The major gas products for $\mathrm{Ni}$ and Inconel were $\mathrm{CO}_{2}$ and $\mathrm{CH}_{4} . \mathrm{H}_{2}$ was the next most abundant product, with $\mathrm{C}_{2}-\mathrm{C}_{3}$ and $\mathrm{CO}$ being the least abundant gas products with the results summarized in Fig. $4 .{ }^{57} \mathrm{Xu}$ showed that activated carbon is an active catalyst for gasification at $600^{\circ} \mathrm{C}$. Glucose was used as a feedstock, but the catalyst quickly deactivated over $4 \mathrm{~h}$. More complex biomass streams including starch and cellulose caused the heat-up zone of the reactor to plug (likely from Inconel reactor walls). Although the activated carbon quickly deactivated, the low cost of activated carbon compared with other catalyst materials still makes it an attractive candidate. ${ }^{59}$

$\mathrm{Ru}$ has been found to be effective in the gasification of three different strains of algal biomass: Spirulina Platensis, Phaeodactylum tricornutum, and Nannochloropsis sp. ${ }^{60-62}$ The temperatures studied for algae gasification over Ru catalysts focus on lower temperatures, i.e. $400^{\circ} \mathrm{C}$. It was found that the major products from gasification were $\mathrm{CO}_{2}, \mathrm{CH}_{4}$, and $\mathrm{H}_{2}$ with lesser amounts of $\mathrm{C}_{2}$ and 

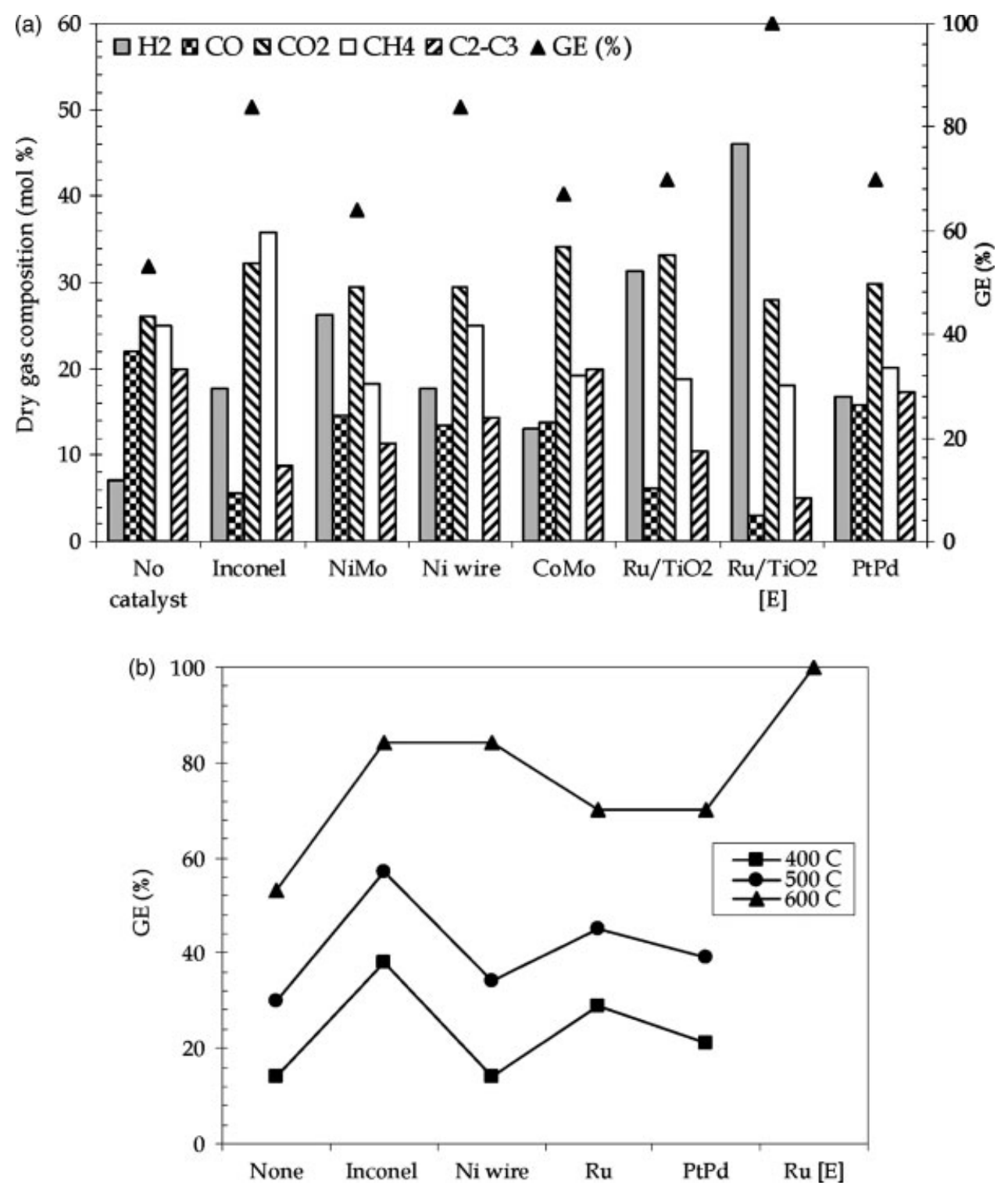

Figure 4. Influence of different catalysts on (a) product gas distribution and gasification efficiency (GE) of microalgae at $600^{\circ} \mathrm{C}$ and (b) GE at different temperatures. [Experimental conditions: concentration, $7.3 \mathrm{wt} \%$; reaction time, $2 \mathrm{~min}$; pressure, 240 bar; catalyst $/ \mathrm{sample}, 0.7 \mathrm{~g} / \mathrm{g}$ for Ru/TiO2, [E] it was 2 $\mathrm{g} / \mathrm{g}$, [E] is excess]. ${ }^{57}$ (Reprinted with permission from Chakinala AG, Brilman DWFW, van Swaaij WPM, Kersten SRA. Catalytic and Non-catalytic Supercritical Water Gasification of Microalgae and Glycerol. Ind Eng Chem Res 2010; 49(3):1113-1122. doi:10.1021/ie9008293. Copyright 2012 American Chemical Society.)

$\mathrm{C}_{3}$ hydrocarbons. In the gasification of Spirulina Platensis at $400^{\circ} \mathrm{C}$, the $\mathrm{CH}_{4}$ to $\mathrm{H}_{2}$ ratio increases from favoring $\mathrm{H}_{2}$ to favoring $\mathrm{CH}_{4}$ with increasing catalyst to algae ratio, ${ }^{60}$ and the same trend is shown in the gasification of Nannochloropsis sp. at $410^{\circ} \mathrm{C} .{ }^{62}$ However, in the gasification of Phaeodactylum tricornutum at $400^{\circ} \mathrm{C}, \mathrm{CH}_{4}$ was always favored over $\mathrm{H}_{2}{ }^{61}$ This difference in the product gas distributions is likely due to the differences in alga biochemical compositions, feed concentrations, and catalyst loadings. The studies of Ru-catalyzed algae gasification also showed that increasing algae feed concentration for both Spirulina Platensis and Nannochloropsis sp., decreases the hydrogen yield. ${ }^{60,62}$ The two studies differ in the reported effect of algae feed concentration on the yield of carbon containing gases. Guan et al. show that the gasification efficiency is independent of the algae feed concentration whereas Stucki etal. show that gasification efficiency decreases with increasing algae feed concentration. ${ }^{60,62}$

\section{Catalyst stability and activity maintenance}

Most of what we know about catalyst degradation during fuel production comes from R\&D related to the petroleum industry. Catalysts in the oil industry normally experience either gas phase or liquid hydrocarbon environments. For hydrothermal catalytic reactions, however, the reaction environment is much different as it is either hot compressed water or supercritical water. There have been only a few studies on catalyst stability and activity maintenance for reactions related to aquatic biomass in hydrothermal media, and these are reviewed in this section.

The use of high temperature or supercritical water as the reaction environment introduces challenges related to catalyst stability. Elliott and coworkers tested different metals for gasification activity in water, and many of the metals underwent oxidation. The metals tested include $\mathrm{Zn}, \mathrm{W}, \mathrm{Mo}, \mathrm{Zn}, \mathrm{Cr}, \mathrm{Re}, \mathrm{Sn}, \mathrm{Pb}, \mathrm{Ni}, \mathrm{Cu}$ and $\mathrm{Ru}$. All were oxidized except for $\mathrm{Ni}, \mathrm{Cu}$, and $\mathrm{Ru}$. Thus, much of the catalyst 
development work has focused on working with the base metals that did not oxidize under those conditions. ${ }^{14}$

Catalyst deactivation typically stems from three main issues: the presence of chemical poisons in the feed stream, a reduction in the number of exposed metal atoms in the catalyst itself, and support issues. All three can be important when hydrothermally processing aquatic biomass.

For the first issue, sulfur is a widely known catalyst poison. Sulfur irreversibly binds to the surface of some metals making the active sites unavailable to perform the desired chemistry. Researchers have studied sulfur poisoning of $\mathrm{Ru}$ due to the effectiveness of $\mathrm{Ru}$ as a gasification catalyst. All forms of sulfur examined to date, including elemental sulfur, sulfates, organic sulfides, and thiols, poison Ru catalysts. ${ }^{12,63}$ Guan presented modeling evidence that Ru deactivation during algae gasification was due to sulfur poisoning. ${ }^{62}$ Waldner showed that Ru irreversibly binds to the sulfate ion to form a Ru(III) complex. ${ }^{64}$ Methods to deal with sulfur poisoning include developing sulfur tolerant catalysts, sulfur removal from the feed stream via HDS, or via formation of sulfur salts. One group proposed dealing with sulfur by transforming it into a non-poisoning form. ${ }^{60}$

The second major cause of catalyst deactivation is loss of catalyst surface area due to crystallite growth, or sintering. Elliott examined the long-term catalyst stability for low temperature gasification $\left(350^{\circ} \mathrm{C}, 21 \mathrm{MPa}\right)$ using $\mathrm{Ni}$ and $\mathrm{Ru}$ catalysts to treat a $10 \%$ solution of phenol in water. When $\mathrm{Ni}$ is doped with $\mathrm{Ru}$, the catalyst is stabilized in terms of crystallite growth. The pure Ni crystallites grew to 700-1000 ̊ compared with a stable $400 \AA$ for Ni doped with Ru. ${ }^{65}$ Doping Ni with $\mathrm{Ag}$ and Cu was even more effective than doping with $\mathrm{Ru}$ as the stable crystallite sizes were 214 and $104 \AA$, respectively. The ruthenium catalyst was found to be stable as the base metal. Skeletal NiRu stability was studied at $400^{\circ} \mathrm{C}$ at $30 \mathrm{MPa}$ in a continuous flow system with synthetic liquefied wood - a mixture of formic acid, acetic acid, ethanol, anisole, and phenol. The crystallites showed evidence of sintering from $9 \mathrm{~nm}$ to $45 \mathrm{~nm}$ in $90 \mathrm{~h}$ which corroborates Elliott's work. ${ }^{64}$

The third major issue with catalyst deactivation deals with support degradation. While this does not directly affect the active catalyst material, it is still important because it affects the effective surface area and pore structure of the catalyst. Supports that are stable in organic solvents may not be stable in aqueous environments. $\gamma-\mathrm{Al}_{2} \mathrm{O}_{3}$, in particular, degrades rapidly to boehmite in supercritical conditions $\left(450^{\circ} \mathrm{C}, 40 \mathrm{MPa}\right)$ and loses $1-2$ orders of magnitude of surface area in $1 \mathrm{~h}^{49}$ Recently, Ravenelle et al. investigated $\mathrm{Pt} / \gamma-\mathrm{Al}_{2} \mathrm{O}_{3}$ and the effects of the Pt precursors on the stability and reactivity of the catalysts in water at $200^{\circ} \mathrm{C}$. While $200^{\circ} \mathrm{C}$ is too low to be effective for algae liquefaction, catalyst degradation that can occur at $200^{\circ} \mathrm{C}$ will also occur at higher temperatures. Ravenelle found that Pt synthesized from $\mathrm{H}_{2} \mathrm{PtCl}_{6}$ led to dissolution of alumina whereas $\mathrm{Pt}$ from $\mathrm{H}_{2} \mathrm{Pt}(\mathrm{OH})_{6}$ did not. The supporting $\gamma-\mathrm{Al}_{2} \mathrm{O}_{3}$ eventually changed to boehmite, but the rate of change varied depending on the Pt precursor used. Pt$\mathrm{OH}$ changed faster than $\mathrm{Pt}-\mathrm{Cl} .{ }^{66,67}$ The stability of $\mathrm{Pt} / \gamma-\mathrm{Al}_{2} \mathrm{O}_{3}$ was further studied in the presence of oxygenated biomass solutions. The presence of polyols (sorbitol and glycerol) in water at $225^{\circ} \mathrm{C}$ inhibited the phase change of $\gamma-\mathrm{Al}_{2} \mathrm{O}_{3}$ to $\alpha-\mathrm{Al}_{2} \mathrm{O}_{3}$. The sorbitol solution was better able to inhibit the degradation of $\gamma-\mathrm{Al}_{2} \mathrm{O}_{3}$ to $\alpha-\mathrm{Al}_{2} \mathrm{O}_{3}$ as only $2 \%$ of the catalyst support changed phase compared with $15 \%$ for the glycerol solution. The inhibition of degradation can also be seen from the BET surface area of the support as shown in Fig. 5. The proposed reason for this inhibition of support degradation is that carbonaceous deposits stabilize

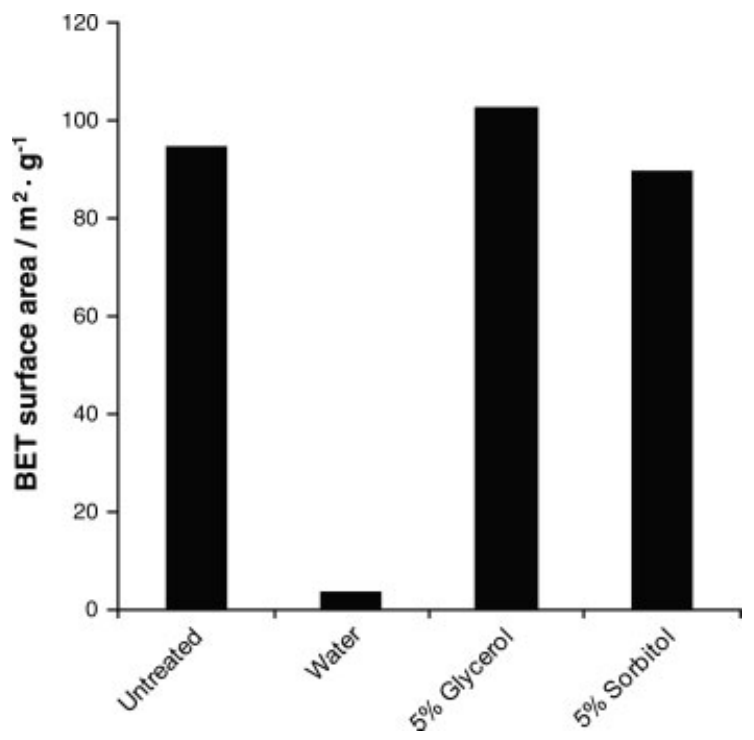

Figure 5. BET surface area of untreated $1 \% \mathrm{Pt} / \mathrm{Al}^{2} \mathrm{O}^{3}$ and after $10 \mathrm{~h}$ treatment at $225^{\circ} \mathrm{C}$ in different solutions. ${ }^{68}$ (With kind permission from Springer Science+Business Media: Top Catal, Stability of $\mathrm{Pt} / \gamma-\mathrm{Al}_{2} \mathrm{O}_{3}$ Catalysts in Model Biomass Solutions, 55, 2012, 162-174, Ravenelle, RM Copeland, JR Van Pelt, AH Crittenden, JC Sievers, C. Fig 6.)

the $\gamma-\mathrm{Al}_{2} \mathrm{O}_{3}{ }^{68}$ In general, stable supports in HTW were found to be monoclinic $\mathrm{ZrO}_{2}$, rutile titania (anatase transforms to rutile), $\alpha-\mathrm{Al}_{2} \mathrm{O}_{3}$, and carbon.

This overview of hydrothermal stability of catalysts indicates that there is a need for more work on the long-term stability of liquefaction, upgrading, and gasification catalysts in high temperature water. Additionally, since sulfur is present within algal biomass, sulfur-resistant catalysts would be very useful. Otherwise, sulfur removal steps will have to be implemented to maintain the longevity of the catalysts. Fortunately, significant sulfur removal from algal bio-oils appears to be possible even by noncatalytic treatment in supercritical water. The stability of catalyst supports is also an important factor in determining the useful life of a catalyst. Research is needed to develop stable supports in high temperature water. Lastly, the stabilization of metals on the supports such that sintering and dissolution can be avoided or minimized is important. Though researchers have studied this topic, it is primarily limited to Ru and Ni catalysts for gasification. The overall improvement of catalysts for hydrothermal conditions will be important for making hydrothermal processing of algal biomass economically viable.

\section{Summary and outlook}

Though only a limited amount of work has been done to date, it is clear that hydrothermal catalytic conversion of algae can produce hydrocarbons for liquid fuels and hydrogen/methane-rich product gases. Thus, there is tremendous potential for this field and the outlook is bright.

The majority of the work to date on producing liquid fuels from hydrothermal conversion of aquatic biomass has focused on homogeneous catalysis by metal salts or alkali. The more recent studies, however, are beginning to examine heterogeneous catalysts due to advantages in separation and selectivity of the catalyst. More work is needed to identify better heterogeneous catalysts for these applications. In particular, the development of non-precious metal based catalysts would provide a major advance. 
Experiments with model compounds are important for elucidating the governing chemistry and pointing out the differences in reactivity that occur in water and in organic reaction media. These efforts have focused mostly on oxygenated compounds (e.g. fatty acids, benzofuran) and fewer studies are available for hydrothermal catalytic treatment of nitrogen- and sulfur-containing compounds. These topics are ripe areas for future work.

Finally, there is a need for more catalyst development work to identify supports and active materials that better resist deactivation in hot compressed water and supercritical water. Deactivation by sulfur atoms is another significant issue when processing aquatic biomass. Catalysts used for supercritical water gasification of algae, in particular, seem to deactivate quickly.

\section{ACKNOWLEDGEMENTS}

The authors acknowledge financial support from a NSF Graduate Research Fellowship. We gratefully thank the National Science Foundation (Grant EFRI-0937992) and the College of Engineering for their financial support.

\section{REFERENCES}

1 Rabalais NN, Turner RE, Wiseman Jr WJ, Gulf of Mexico Hypoxia, a.k.a. "The Dead Zone". Annu Rev Ecol Syst 33:235-263 (2002).

2 Alexander RB, Smith RA, Schwarz GE, Boyer EW, Nolan JV and Brakebill JW. Differences in phosphorus and nitrogen delivery to the Gulf of Mexico from the Mississippi River basin. Environ Sci Technol 42:822-830 (2008).

3 Lewis NS and Nocera DG, Powering the planet: chemical challenges in solar energy utilization. Proc Nat Acad Sci USA 103:15729-15735 (2006).

4 Kim S and Dale BE, Global potential bioethanol production from wasted crops and crop residues. Biomass Bioenergy 26:361-375 (2004).

5 Pimentel D and Patzek TW, Ethanol production using corn, switchgrass, and wood; biodiesel production using soybean and sunflower. Nat Resources Res 14:65-76 (2005).

6 Weyer K, Bush D, Darzins A and Willson B, Theoretical maximum algal oil production. BioEnergy Res 3:204-213 (2010).

7 Vasudevan P and Briggs M, Biodiesel production - current state of the art and challenges. J Ind Microbiol Biotechnol 35:421-430 (2008).

8 Savage $P E, A$ perspective on catalysis in sub- and supercritical water. J Supercrit Fluids 47:407-414 (2009).

9 Levine RB, Pinnarat T and Savage PE, Biodiesel production from wet algal biomass through in situ lipid hydrolysis and supercritical transesterification. Energy Fuels 24:5235-5243 (2010).

10 Levine RB, Bollas AA, Durham MD and Savage PE, Triflate-catalyzed (trans)esterification of lipids within carbonized algal biomass. Bioresource Technol 111:222-229 (2012).

11 Savage PE, Levine RB and Huelsman CM, Hydrothermal processing of biomass. In Thermochemical Conversion of Biomass to Liquid Fuels and Chemicals. The Royal Society of Chemistry, 192-221 (2010).

12 Peterson AA, Vogel F, Lachance RP, Froling M, Antal Jr MJ and Tester $J W$, Thermochemical biofuel production in hydrothermal media: a review of sub- and supercritical water technologies. Energy Environ Sci 1:32-65 (2008)

13 Huber GW, Iborra S and Corma A, Synthesis of transportation fuels from biomass: chemistry, catalysts, and engineering. Chem Rev 106:4044-4098 (2006).

14 Elliott DC, Catalytic hydrothermal gasification of biomass. Biofuels Bioprod Biorefin 2:254-265 (2008).

15 Brennan $L$ and Owende $P$, Biofuels from microalgae - a review of technologies for production, processing, and extractions of biofuels and co-products. Renew Sustain Energy Rev 14:557- 577 (2010).

16 Tran NH, Bartlett JR, Kannangara GSK, Milev AS, Volk H and Wilson MA. Catalytic upgrading of biorefinery oil from micro-algae. Fuel 89:265-274 (2010).
17 Biller $\mathrm{P}$ and Ross $A B$, Potential yields and properties of oil from the hydrothermal liquefaction of microalgae with different biochemical content. Bioresource Technol 102:215-225 (2010).

18 Minowa T, Yokoyama S, Kishimoto M and Okakura T, Oil production from algal cells of Dunaliella tertiolecta by direct thermochemical liquefaction. Fuel 74:1735-1738 (1995).

19 Dote Y, Sawayama S, Inoue S, Minowa T and Yokoyama S, Recovery of liquid fuel from hydrocarbon-rich microalgae by thermochemical liquefaction. Fuel 73:1855-1857 (1994).

20 Inoue S, Dote Y, Sawayama S, Minowa T, Ogi T and Yokoyama S, Analysis of oil derived from liquefaction of Botryococcus braunii. Biomass Bioenergy 6:269-274 (1994).

21 Ross A, Biller P, Kubacki M, Li H, Lea-Langton A and Jones J, Hydrothermal processing of microalgae using alkali and organic acids. Fuel 89:2234-2243 (2010).

22 Shuping Z, Yulong W, Mingde Y, Kaleem I, Chun L and Tong J, Production and characterization of bio-oil from hydrothermal liquefaction of microalgae Dunaliella tertiolecta cake. Energy 35:5406 - 5411 (2010).

23 Yang $Y$, Feng $C$, Inamori $Y$ and Maekawa $T$, Analysis of energy conversion characteristics in liquefaction of algae. Resource Conserv Recycle 43:21-33 (2004).

24 Zhou D, Zhang L, Zhang S, Fu H and Chen J, Hydrothermal liquefaction of macroalgae Enteromorpha prolifera to bio-oil. Energy Fuels 24:4054-4061 (2010).

25 Appell HR, Fu YC, Friedman S, Yavorskly PM and Wender I, Converting organic wastes to oil. Agric Eng 15:17-19 (1972).

26 Dote Y, Inoue S, Ogi T and ya Yokoyama S, Distribution of nitrogen to oil products from liquefaction of amino acids. Bioresource Technol 64:157-160 (1998).

27 Changi S, Minghan $Z$ and Savage PE, Hydrothermal reaction kinetics and pathways of phenylalanine alone and in binary mixtures. Chem SUS Chem 5: 1743-1757 (2012).

28 Dote $Y$, Inoue S, Ogi T and Yokoyama S, Studies on the direct liquefaction of protein-contained biomass: the distribution of nitrogen in the products. Biomass Bioenergy 11:491-498 (1996).

29 Li L, Coppola E, Rine J, Miller JL and Walker D, Catalytic hydrothermal conversion of triglycerides to non-ester biofuels. Energy Fuels 24:1305-1315 (2010).

30 Duan $P$ and Savage PE, Hydrothermal liquefaction of a microalga with heterogeneous catalysts. Ind Eng Chem Res 50:52-61 (2011).

31 Duan $P$ and Savage PE, Upgrading of crude algal bio-oil in supercritical water. Bioresource Technol 102:1899-1906 (2011).

32 Duan P and Savage PE, Catalytic hydrotreatment of crude algal bio-oil in supercritical water. Appl Catal B 104:136-143 (2011).

33 Duan P, Savage PE. Catalytic treatment of crude algal bio-oil in supercritical water: optimization studies. Energy Environ Sci 4: $1447-1456$ (2011).

34 Brown TM, Duan P and Savage PE, Hydrothermal liquefaction and gasification of Nannochloropsis sp. Energy Fuels 24:3639-3646 (2010).

35 Valdez PJ, Dickinson JG and Savage PE, Characterization of product fractions from hydrothermal liquefaction of Nannochloropsis sp. and the influence of solvents. Energy Fuels 25:3235-3243 (2011).

$36 \mathrm{Fu} \mathrm{J,} \mathrm{Lu} \mathrm{X}$ and Savage PE, Hydrothermal decarboxylation and hydrogenation of fatty acids over Pt/C. Chem Sus Chem 4:481-486 (2011).

$37 \mathrm{Fu} \mathrm{J,} \mathrm{Lu} \mathrm{X} \mathrm{and} \mathrm{Savage} \mathrm{PE,} \mathrm{Catalytic} \mathrm{hydrothermal} \mathrm{deoxygenation} \mathrm{of}$ palmitic acid. Energy Environ Sci 3:311-317 (2010).

38 Snåre M, Kubicková I, Mäki-Arvela P, Eränen K and Murzin DY, Heterogeneous catalytic deoxygenation of stearic acid for production of biodiesel. Ind Eng Chem Res 45:5708-5715 (2006).

39 Watanabe M, Catalytic decarboxylation of acetic acid with zirconia catalyst in supercritical water. App/ Catal A 219:149-156 (2001).

40 Watanabe $\mathrm{M}$, lida $\mathrm{T}$ and Inomata $\mathrm{H}$, Decomposition of a long chain saturated fatty acid with some additives in hot compressed water. Energy Conversion Manage 47:3344-3350 (2006).

41 Fu J, Shi F, Thompson LT, Lu X and Savage PE, Activated carbons for hydrothermal decarboxylation of fatty acids. ACS Catal 1:227-231 (2011).

42 Dickinson JG, Poberezny JT and Savage PE, Deoxygenation of Benzofuran in supercritical water over a platinum catalyst. Appl Catal B: Environmental 123-124:357-366 (2012).

43 Garcia Alba L, Torri C, Samor C, van der Spek J, Fabbri D, Kersten SRA, et al, Hydrothermal treatment (HTT) of microalgae: evaluation of 
the process as conversion method in an algae biorefinery concept. Energy Fuels 26:642-657 (2012).

44 Jena $U$ and Das KC, Comparative evaluation of thermochemical liquefaction and pyrolysis for bio-oil production from microalgae. Energy Fuels 25:5472-5482 (2011).

45 Jena U, Das KC and Kastner JR, Effect of operating conditions of thermochemical liquefaction on biocrude production from Spirulina platensis. Bioresource Technol 102:6221-6229 (2011).

46 Torri C, Garcia Alba L, Samor C, Fabbri D and Brilman DWFW, Hydrothermal treatment (HTT) of microalgae: detailed molecular characterization of $\mathrm{HTT}$ Oil in view of $\mathrm{HTT}$ mechanism elucidation. Energy Fuels 26:658-671 (2012).

47 Duan $\mathrm{P}$ and Savage $\mathrm{PE}$, Catalytic hydrothermal hydrodenitrogenation of pyridine. Appl Catal B 108-109:54-60 (2011).

48 Yuan PQ, Cheng ZM, Zhang XY and Yuan WK, Catalytic denitrogenation of hydrocarbons through partial oxidation in supercritical water. Fuel 85:367-373 (2006).

49 Yuan $P Q$, Cheng ZM, Jiang WL, Zhang R and Yuan WK, Catalytic desulfurization of residual oil through partial oxidation in supercritical water. J Supercrit Fluids 35:70-75 (2005).

50 Adschiri $T$, Shibata $R$, Sato $T$, Watanabe $M$ and Arai $K$ Catalytic hydrodesulfurization of Dibenzothiophene through partial oxidation and a water-gas shift reaction in supercritical water. Ind Eng Chem Res 37(7):2634-2638 (1998).

51 Becker EW, Micro-algae as a source of protein. Biotechnol Adv 25:207-210 (2007)

52 Wofford WT and Gloyna EF, Solubility of potassium hydroxide and potassium phosphate in supercritical water. J Chem Eng Data 40:968-973 (1995).

53 Khan MS and Rogak SN, Solubility of $\mathrm{Na}_{2} \mathrm{SO} 4, \mathrm{Na} 2 \mathrm{CO} 3$ and their mixture in supercritical water. J Supercrit Fluids 30:359-373 (2004).

54 Watanabe $\mathrm{M}$, Inomata $\mathrm{H}$, Osada $\mathrm{M}$, Sato T, Adschiri T and Arai $\mathrm{K}$, Catalytic effects of $\mathrm{NaOH}$ and $\mathrm{ZrO} 2$ for partial oxidative gasification of $\mathrm{n}$-hexadecane and lignin in supercritical water. Fuel 82:545-552 (2003).

55 Sealock Jr. J and Elliott DC, Method For The Catalytic Conversion Of Lignocellulosic Materials. U.S. Patent 5019135 (1991).

56 Kruse A, Meier D, Rimbrecht $P$ and Schacht M, Gasification of Pyrocatechol in supercritical water in the presence of potassium hydroxide. Ind Eng Chem Res 39:4842-4848 (2000).
57 Chakinala AG, Brilman DWFW, van Swaaij WPM and Kersten SRA Catalytic and non-catalytic supercritical water gasification of microalgae and glycerol. Ind Eng Chem Res 49:1113-1122 (2010).

58 Guo Y, Wang SZ, Xu DH, Gong YM, Ma HH and Tang XY, Review of catalytic supercritical water gasification for hydrogen production from biomass. Renew Sustain Energy Rev 14:334-343 (2010).

$59 \mathrm{Xu} \mathrm{X,} \mathrm{Matsumura} \mathrm{Y,} \mathrm{Stenberg} \mathrm{J} \mathrm{and} \mathrm{Antal} \mathrm{MJ,} \mathrm{Carbon-catalyzed}$ gasification of organic feedstocks in supercritical water. Ind Eng Chem Res 35:2522-2530 (1996).

60 Stucki S, Vogel F, Ludwig C, Haiduc AG and Brandenberger M, Catalytic gasification of algae in supercritical water for biofuel production and carbon capture. Energy Environ Sci 2:535-541 (2009).

61 Haiduc A, Brandenberger M, Suquet S, Vogel F, Bernier-Latmani R and Ludwig C, SunCHem: an integrated process for the hydrothermal production of methane from microalgae and $\mathrm{CO}_{2}$ mitigation. J Appl Phycol 21:529-541 (2009).

62 Guan Q, Wei C and Savage PE, Hydrothermal gasification of Nannochloropsis sp. with Ru/C. Energy Fuels 61:139-145 (2012).

63 Osada M, Hiyoshi N, Sato O, Arai K and Shirai M, Effect of sulfur on catalytic gasification of lignin in supercritical water. Energy Fuels 21:1400-1405 (2012).

64 Waldner $\mathrm{MH}$, Krumeich $\mathrm{F}$ and Vogel F, Synthetic natural gas by hydrothermal gasification of biomass: selection procedure towards a stable catalyst and its sodium sulfate tolerance. J Supercrit Fluids 43:91-105 (2007).

65 Elliott DC, Hart TR and Neuenschwander GG, Chemical processing in high-pressure aqueous environments. 8. Improved catalysts for hydrothermal gasification. Ind Eng Chem Res 45:3776-3781 (2006).

66 Ravenelle RM, Copeland JR, Kim WG, Crittenden JC and Sievers C, Structural changes of $\gamma-\mathrm{Al}_{2} \mathrm{O}_{3}$ - supported catalysts in hot liquid water. ACS Catal 1:552-561 (2011).

67 Ravenelle RM, Diallo FZ, Crittenden JC and Sievers C, Effects of metal precursors on the stability and observed reactivity of $\mathrm{Pt} / \gamma-\mathrm{Al}_{2} \mathrm{O}_{3}$ catalysts in aqueous phase reactions. Chem Catal Chem 4:492-494 (2012).

68 Ravenelle R, Copeland J, Van Pelt A, Crittenden J and Sievers C, Stability of $\mathrm{Pt} / \gamma-\mathrm{Al}_{2} \mathrm{O}_{3}$ catalysts in model biomass solutions. Top Catal 55:162-174 (2012). 